Volume 3, No. 2 Januari 2020

\title{
PENINGKATAN HASIL BELAJAR MATEMATIKA POKOK BAHASAN \\ KESEBANGUNAN BANGUN DATAR MELALUI MEDIA PAPAN BERPAKU PADA SISWA TUNANETRA KELAS IX DI SLB-A TPA JEMBER
}

\author{
ARIDA CHOIRUN NISA, S.Pd, M.Pd
}

SLB-A TPA JEMBER

\begin{abstract}
ABSTRAK
Penelitian ini bertujuan untuk meningkatkan hasil belajar matematika pokok bahasan kesebangunan bangun datar melalui media papan berpaku pada siswa kelas IX semester ganjil di SLB-A (tunanetra) TPA Jember. Penelitian ini menggunakan desain penelitian tindakan kelas (PTK). Subyek penelitian tindakan kelas ini pada mata pelajaran matematika, khususnya pada materi pokok tentang kesebangunan bangun datar, dengan jumlah 3 siswa. Tempat penelitian adalah di SLB-A (tunanetra) TPA jember. Penelitian ini dilaksanakan dalam dua siklus, siklus I pada tanggal $01-09$ juli 2015 , siklus II pada tanggal $16-23$ juli 2015 dan sesuai dengan jadwal pelajaran di sekolah. Hasil penelitian ditemukan bahwa pembelajaran dengan media papan berpaku memiliki dampak positif dalam meningkatkan hasil belajar matematika tentang kesebangunan bangun datar pada siswa kelas IX SLB-A (tunanetra) TPA Jember. Hal ini dapat dilihat pada siklus I, dari 3 siswa yang tuntas sebanyak 2 siswa (67\%) dan yang belum tuntas sebanyak 1 siswa (33\%). Sedangkan pada siklus II, semua siswa telah tuntas (100\%). Jadi, setelah diadakan siklus II hasil belajar siswa meningkat sebesar $33 \%$.
\end{abstract}

Kata Kunci: Hasil Belajar, Matematika, Kesebangunan Bangun Datar, Media Papan Berpaku

\section{PENDAHULUAN}

Matematika sebagai salah satu mata pelajaran di SLB-A (Tunanetra) perlu mendapatkan perhatian khusus sebab Matematika dapat mempersiapkan siswa agar dapat menggunakan pola pikir matematik dalam kehidupan seharihari, dan dalam mempelajari berbagai ilmu. Matematika perlu diberikan kepada semua peserta didik mulai dari sekolah dasar untuk membekali peserta didik dengan kemampuan berpikir logis, analitis, sistematis, kritis, dan kreatif, serta kemampuan bekerjasama. Kompetensi tersebut diperlukan agar peserta didik dapat memiliki kemampuan memperoleh, mengelola, dan memanfaatkan informasi untuk bertahan hidup pada keadaan yang selalu berubah, tidak pasti, dan kompetitif (Depdikbud, 2006, hlm. 416).

Matematika merupakan salah satu jenis dari enam materi ilmu yaitu Matematika, Fisika, Biologi, Psikologi, ilmu-ilmu sosial dan linguistik. Didasarkan pada pandangan konstruktivisme, hakikat Matematika yakni anak yang belajar Matematika dihadapkan pada masalah tertentu berdasarkan konstruksi pengetahuan yang diperolehnya ketika belajar dan anak berusaha memecahkannya (Hamzah, 2007, hlm. 126). Ciri utama Matematika adalah penalaran deduktif yaitu kebenaran suatu konsep atau pernyataan yang diperoleh sebagai akibat logis dari kebenaran sebelumnya. Namun demikian, dalam pembelajaran 
pemahaman konsep sering diawali secara induktif melalui pengalaman peristiwa nyata. Proses induktif-deduktif dapat digunakan untuk mempelajari konsep Matematika. Selama mempelajari matematika dikelas, aplikasi hasil rumus atau sifat yang diperoleh dari penalaran deduktif maupun induktif sering ditemukan meskipun tidak secara formal hal ini disebut dengan belajar bernalar (Depdiknas, 2003, hlm. 5).

Adapun tujuan pembelajaran Matematika yaitu: (1) menumbuhkan dan mengembangkan keterampilan berhitung (menggunakan bilangan) sebagi alat dalam kehidupan sehari-hari, (2) menumbuhkan kemampuan siswa, yang dapat dialihgunakan, melalui kegiatan matematika, mengembangkan pengetahuan dasar matematika sebagai bekal belajar lenih lanjut di sekolah lanjutan tingkat pertama, (4) membentuk sikap logis, kritis, cermat, kreatif dan disiplin (Dipdiknas, 2006, hlm. 58). Salah satu hal yang mempengaruhi hasil belajar siswa adalah pengalaman siswa, dimana pengalaman siswa belajar matematika sangat dipengaruhi oleh metode yang digunakan guru dalam pembelajaran. Sehingga guru dituntut agar mampu menyiasati dan mencermati keadaan tersebut sehingga dalam pembelajaran di kelas menjadi efektif. Salah satunya dengan pemilihan metode pembelajaran yang sesuai dengan materi yang akan disampaikan.

\section{Pendidikan}

Matematika

merupakan salah satu mata pelajaran yang paling tidak disukai oleh siswa (Lithanta, 2008, hlm. 3). Matematika sering dianggap sebagai pelajaran yang sulit dipahami, baik berupa teori maupun konsepnya. Hal ini mengakibatkan prestasi belajar matematika cenderung belum memuaskan. Berdasarkan hasil observasi langsung pembelajaran Matematika terhadap siswa kelas IX SLB-A (Tunanetra) TPA Jember, diperoleh bahwa hasil belajar siswa sangat rendah. Hal ini tampak pada nilai hasil belajar siswa kelas IX yang berjumlah 3 siswa khususnya materi Kesebangunan Bangun Datar yaitu 1 siswa (33\%) mendapatkan nilai antara 069 dari nilai maksimal 100, dan hanya 2 siswa $(67 \%)$ mendapat nilai antara 70 100. Sedangkan Kriteria Ketuntasan Minimum (KKM) yang ditetapkan sekolah untuk mata pelajaran Matematika adalah sebesar 70. Dengan demikian pembelajaran Matematika pada materi Kesebangunan Bangun Datar masih belum tuntas sehingga perlu dilakukan perbaikan pembelajaran.

Dari data tersebut dapat dianalisis bahwa yang menyebabkan rendahnya hasil belajar siswa kelas IX di SLB-A (Tunanetra) TPA Jember antara lain: (1) Mata pelajaran Matematika tidak disukai dan kurang diminati siswa bahkan dianggap mata pelajaran yang paling sulit dipahami dan di mengerti; (2) Dalam pembelajaran Matematika, guru menyampaikan materi masih dengan menggunakan metode ceramah dan pemberian tugas; (3) Siswa hanya diajarkan materi perkalian melalui hafalan sehingga siswa sering mengalami kesulitan, pembelajaran menjadi monoton dan membosankan; (4) Kegiatan siswa hanyalah duduk mendengarkan penjelasan guru dan mengerjakan tugas yang diberikan oleh guru; (5) Selama pembelajaran 
matematika guru jarang menggunakan alat peraga dan media pembelajaran.

Berdasarkan hasil analisis, permasalahan di atas disebabkan oleh dominasi guru masih tinggi, peran guru dalam proses pembelajaran sebagai penyebar ilmu kurang berperan sebagai fasilitator, guru masih banyak tergantung pada buku, guru masih dominan menggunakan ceramah dan mencatat, guru kurang mengoptimalkan bekerja bersama-sama dan siswadianggap lulus tes atau dapat mengerjakan tes tanpa memperhatikan aspek lain seperti kejujuran, pengendalian diri, penghargaan kepada orang lain, kemampuan bekerja sama. Demikian gambaran situasi pembelajaran saat ini yang terjadi di lapangan.

Karena berbagai penyebab di atas maka pembelajaran Matematika di SLBA (Tunanetra) TPA Jember khususnya di kelas IX perlu diperbaiki baik dalam strategi pembelajaran maupun media pembelajaran yang digunakan. Strategi pembelajaran adalah komponen cara pembelajaran yang harus dilakukan oleh guru dalam menyampaikan pesan atau materi pembelajaran agar mencapai tujuan pembelajaran. Oleh karena itu, peneliti menggunakan media Papan Berpaku.

Media Papan Berpaku yang peneliti maksud adalah sebuah papan dari kayu atau bahan trilek yang persegi panjang yang kemudian diberi garis lurus dan melintang yang membentuk bujur sangkar sebagai satuan terkecil. Kemudian setiap titik bujur sangkar diberi paku kecil untuk menempelkan karet untuk membentuk sebuah bangun datar.
Pembelajaran geometri pada siswa dimulai dari bangun yang sederhana yang sudah dikenal sebelumnya dan mudah dijumpai di sekitar kita atau di dalam kelas. Bangun-bangun geometri yang yang diajarkan di kelas IX adalah untuk memahami Kesebangunan Bangun Datar, karena di sini siswa belum diminta untuk menghitung keliling, luas dan isi (volume). Pada siswa juga cukup dikenalnya nama-nama bangun geometri, misalnya segi tiga, segi lima, segi enam, persegi, persegi panjang dan lingkaran.

Papan berpaku barguna sebagai alat bantu pembelajaran Matematika di SLB-A (Tunanetra) untuk menanamkan konsep atau pengertian geometri, seperti pengenalan geometri, seperti pengenalan geometri bangun datar, keliling bangun datar, menghitung luas bangun datar.

Media papan berpaku ini dapat diperguanakan di tingkat sekolah dasar sampai sekolah lanjutan. Dalam proses belajar mengajar alat ini alat ini dipakai untuk menjelaskan konsep ciri-ciri bangun datar seperti bujur sangkar, persegi panjang, segi tiga, jajaran genjang, dan lain-lain. Dengan alat ini siswa dapat membedakan bangun datar yang satu dengan bangun datar yang lainnya. Keterampilan lainnya yang diperoleh siswa melalui alat ini adalah siswa terampil membuat dan menggambar macam-macam bangun datar

Dengan demikian, perlu dilakukan perbaikan pembelajaran Matematika melalui Penelitian Tindakan Kelas dengan judul: "Peningkatan Hasil Belajar Matematika Pokok Bahasan Kesebangunan Bangun Datar Melalui Media Papan Berpaku Pada Siswa 
Volume 3, No. 2 Januari 2020

Tunanetra Kelas IX di SLB-A (Tunanetra) TPA Jember."

\section{METODE}

Subyek penelitian tindakan kelas ini adalah mata pelajaran Matematika, khususnya pada materi pokok tentang Kesebangunan Bangun Datar, pada siswa kelas IX SLB-A (Tunanetra) TPA Jember dengan jumlah 3 siswa. Tempat penelitian pembelajaran adalah di SLBA (Tunanetra) TPA Jember.

Penelitian dilaksanakan dalam dua siklus, siklus I pada tanggal $01-09$ Juli 2015, siklus II pada tanggal 16 - 23 Juli 2015 dan sesuai dengan jadwal pelajaran di sekolah. Pihak yang membantu penelitian oleh kepala sekolah sebagai Supervisor 1 dan teman sejawat sebagai Supervisor 2 sebagai pengamat selama melaksanakan penelitian.

Penelitian ini menggunakan desain penelitian tindakan kelas (PTK). Pada hakekatnya PTK merupakan suatu proses dimana melalui proses ini guru menginkan adanya perbaikan, peningkatan, dan perubahan pembelajaran lebih baik agar tujuan pembelajaran dapat tercapai secara optimal.

Penelitian ini dilaksanakan berupa proses berdaur yang terdiri dari empat tahap. Keempat tahap tersebut dipandang sebagai siklus spiral dan dapat digambarkan sebagai berikut:

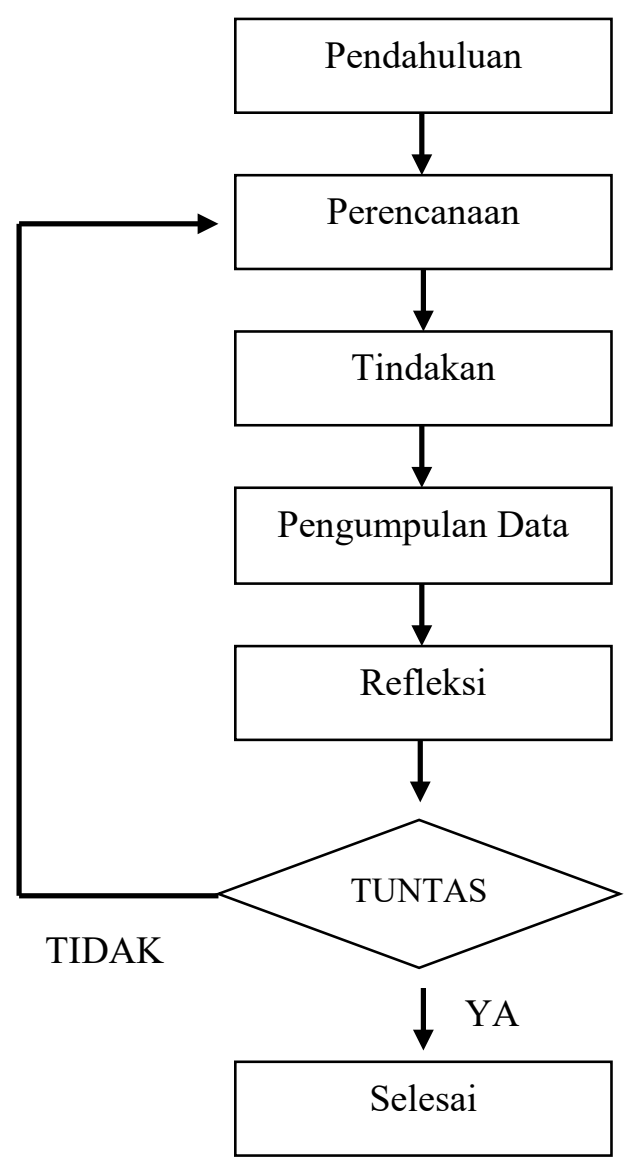

\section{Gambar 1. Alur Penelitian Tindakan Kelas}

(Sumber: Mukhlis, 2003:5)

Tindakan pendahuluan ini dilakukan sebelum pelaksanaan dari siklus I. Langkah pertama yang dilakukan dalam tindakan pendahuluan ini adalah observasi untuk mendapatkan informasi tentang keadaan sekolah dan mengetahui masalah-masalah yang dihadapi oleh guru dan siswa sebelum pengambilan data. Berdasarkan data hasil belajar siswa dalam pembelajaran sebelum tindakan perbaikan, maka dapat dijadikan tolak ukur mengatasi permasalahan dengan menggunakan Media Papan Berpaku.

\section{Siklus I}

Pada tahap perencanaan perbaikan ini langkah-langkah yang dilakukan 
meliputi: Pertama, menyusun RPP (Rencana Pelaksanaan Pembelajaran) untuk observasi proses pembelajaran yang bisa dilakukan guru, pada mata pelajaran Matematika menggunakan Media Papan Berpaku berdasarkan materi pelajaran yang diberikan; Kedua, mempersiapkan daftar pengamatan sebagai acuan untuk mengumpulkan data tentang hasil belajar siswa dalam mengikuti pelajaran Matematika serta menyiapkan bahan penelitian serta menyiapkan tes di akhir pelajaran yang dimaksudkan untuk mengetahui perkembangan hasil belajar siswa. Ketiga, menyusun langkah-langkah pembelajaran sesuai dengan pokok bahasan yang akan diajarkan.

Pada tahap pelaksanaan perbaikan ini langkah-langkah yang dilakukan meliputi: Pertama, dilakukan melalui prosedur penelitian tindakan kelas, yaitu perencanaan, pelaksanaan, pengamatan, dan refleksi; Kedua, saat pelaksanaan tindakan, peneliti bertindak sebagai guru dan dibantu oleh kepala sekolah sebagai Supervisor 1 dan teman sejawat sebagai Supervisor 2; Ketiga, Supervisor 1 bertugas sebagai pembimbing dalam penyusun laporan penelitian perbaikan pembelajaran, sedangkan Supervisor 2 bertugas sebagai pengamat yang memantau jalannya proses pembelajaran yang hasilnya berupa catatan data kegiatan pembelajaran. Keempat, menerapkan langkah-langkah pembelajaran sesuai dengan pokok bahasan dan Media Papan Berpaku.

Pada tahap pengumpulan data ini yang dilakukan meliputi: Pertama, pada waktu guru mengajar, peneliti dibantu teman sejawat untuk melakukan pengumpulan data dengan cara observasi/pengamatan, wawancara, dan dokumentasi, selama kegiatan pembelajaran berlangsung untuk mengetahui sejauh mana data hasil belajar siswa sebelum dan sesudah diberi tindakan; Kedua, untuk mengetahui perkembangan hasil belajar, siswa diberi angket hasil belajar pada awal kegiatan sebelum melakukan tindakan dan juga pada lembar jawaban observasi hasil belajar yang dibawa peneliti. Untuk mengetahui perkembangan hasil belajar siswa dilakukan melalui tes yang diberikan setiap akhir siklus.

Dari hasil observasi, dilakukan analisis pada tindakan I kemudian dilanjutkan dengan refleksi untuk mengetahui atau menemukan kekuatan dan kelemahan Media Papan Berpaku, yang dilakukan bersama teman sejawat, perlu dilakukan tindakan selanjutnya.

\section{Siklus II}

Pada tahap perencanaan perbaikan ini langkah-langkah yang dilakukan meliputi: Pertama, rencana tindakan kelas siklus II disusun berdasarkan hasil analisis dan refleksi selama siklus I. Pada siklus II guru menyampaikan materi dengan Media Papan Berpaku dengan ditambah media kartu bilangan; Kedua, mempersiapkan daftar pengamatan sebagai acuan untuk mengumpulkan data tentang hasil belajar siswa dalam mengikuti pelajaran Matematika serta menyiapkan bahan penelitian serta menyiapkan tes di akhir pelajaran yang dimaksudkan untuk mengetahui perkembangan hasil belajar siswa. Ketiga, menyusun langkahlangkah pembelajaran sesuai dengan pokok bahasan yang akan diajarkan.

Pada tahap pelaksanaan perbaikan ini yang dilakukan meliputi: Pertama, 
tindakan pada siklus II disusun berdasarkan refleksi dari hasil tindakan pertama. Hasil analisis data pada siklus I tersebut digunakan sebagai acuan refleksi untuk menentukan rencana tindakan tahap ke II dengan mengadakan beberapa perbaikan dari rencana tindakan tahap pertama; Kedua, pada siklus II ini lebih banyak memberikan kesempatan pada siswa untuk memahami Kesebangunan Bangun Datar. Pada saat pelaksanaan tindakara. ini didapat hasil rekaman data tentang kegiatan pembelajaran dari teman sejawat.

Untuk mengetahui perkembangan hasil belajar siswa dilakukan pengisian lembar observasi hasil belajar siswa dan melalui tes yang diberikan setiap akhir siklus. Dari hasil observasi, dilakukan analisis pada tindakan II kemudian dilanjutkan dengan refleksi untuk mengetahui atau menemukan kekuatan dan kelemahan Media Papan Berpaku, yang dilakukan bersama teman sejawat, perlu dilakukan tindakan selanjutnya.

Metode pengumpulan data yang digunakan dalam penelitian ini adalah:

\section{Lembar Kerja Siswa (LKS)}

Lembar Kerja Siswa (LKS) adalah lembaran yang berisi tugas yang harus dikerjakan oleh siswa. LKS biasanya berupa petunjuk, langkah untuk menyelesaikan tugas, suatu tugas yang diperintahkan dalam lembar kegiatan harus jelas kompetensi dasar yang akan dicapai.

\section{Lembar Observasi}

Lembar observasi adalah lembar yang berfungsi untuk mengamati dan mengukur tingkat keberhasian atau ketercapaian tujuan pembelajaran pada kegiatan pembelajaran di kelas. Lembar ini digunakan untuk mengamati peneliti dalam kegiatan perbaikan pembelajaran dengan menggunakan Media Papan Berpaku.

\section{Tes Formatif}

Tes formatif adalah tes-tes yang dilakukan selama proses pembelajaran yang masih berlangsung, agar siswa dan guru memperoleh informasi (feedback) mengenai kemajuan yang telah dicapai.

Adapun jenis tes antara lain:

Tes obyektif, yaitu tes tulis untuk mengukur proses berpikir, ingatan, pemahaman, dan penerapan.

b. Tes uraian subyektif/uraian, merupakan bentuk tes tertulis untuk mengukur kemampuan belajar yang bersifat pembahasan, analisis, sintesis, dan evaluasi.

Dalam penelitian perbaikan pembelajaran ini menggunakan tes tulis subyektif dengan 10 soal, pelaksanaannya membutuhkan waktu 45 menit.

Dalam penelitian tindakan kelas, analisis data yang digunakan juga bersifat reflektif, artinya selalu direfleksikan pada proses pembelajaran. Dengan demikian setiap akhir pelaksanaan tindakan dilakukan kajian terhadap kelemahan kemudian diwujudkan dalam perbaikan rencana tindakan, setelah itu dilaksanakan ke dalam pelaksanaan tindakan siklus berikutnya.

Analisis data pada penelitian ini menggunakan statistik deskriptif. Menata, menyajikan, dan menganalisis data dapat dilakukan dengan menentukan skor rata-rata hitung dan persen/proposisi. Data disajikan dalam bentuk persentase untuk mengetahui peningkatan hasil belajar siswa. Hasil 
Volume 3, No. 2 Januari 2020

analisis tersebut menggambarkan tercapainya hasil belajar Matematika menggunakan Media Papan Berpaku. Untuk menghitung persentase peningkatan hasil belajar siswa digunakan dengan teknik sebagai berikut:

$$
H B=\frac{N 1+N 2+N 3}{3}=\ldots
$$

Keterangan:

HB: Nilai Hasil Belajar

N1 : Nilai Ulangan Harian

N2 : Nilai Tugas

N3 : Nilai Sumatif

Untuk menentukan peningkatan hasil belajar diperoleh dari perubahan skor hasil belajar pra siklus ke siklus I, siklus II, atau siklus berikutnya.

Tabel 3.1. Kategori Persentase

\section{Hasil Belajar Siswa}

\begin{tabular}{cc}
\hline Skor rata-rata & Kategori \\
\hline $\mathrm{P} \geq 90 \%$ & Sangat Baik \\
\hline $80 \% \leq \mathrm{P}<90 \%$ & Baik \\
\hline $65 \% \leq \mathrm{P}<80 \%$ & Cukup Baik \\
\hline $55 \% \leq \mathrm{P}<65 \%$ & Kurang Baik \\
\hline $\mathrm{P}<55 \%$ & Sangat Kurang \\
\hline
\end{tabular}

\section{HASIL DAN PEMBAHASAN}

\section{Siklus I}

Pada tahap ini peneliti menyusun perangkat pembelajaran yang terdiri dari rencana pelajaran 1 , LKS 1 , soal tes formatif 1 dan media pembelajaran yang mendukung. Selain itu juga dipersiapkan lembar observasi pengolahan pembelajaran dengan Media Papan Berpaku, dan lembar observasi aktivitas guru dan siswa.

Pelaksanaan kegiatan belajar mengajar untuk siklus I dilaksanakan pada tanggal 01 - 09 Juli 2015 di Kelas
IX dengan jumlah siswa 3 anak. Dalam hal ini peneliti bertindak sebagai guru, sedangkan yang bertindak sebagai pengamat adalah rekan sejawat. Adapun proses belajar mengajar mengacu pada rencana pelajaran yang telah dipersiapkan. Pengamatan (observasi) dilaksanakan bersamaan dengan pelaksaaan belajar mengajar.

Pada akhir proses belajar mengajar siswa diberi tes formatif I dengan tujuan untuk mengetahui tingkat keberhasilan siswa dalam proses belajar mengajar yang telah dilakukan. Adapun data hasil belajar Matematika pada siklus I adalah sebagai berikut:

\section{Tabel 1. Hasil Belajar Matematika}

\section{Pada Siklus I}

\begin{tabular}{|c|c|c|c|c|}
\hline No. & Nama & $\begin{array}{c}\text { Nil } \\
\text { ai }\end{array}$ & $\begin{array}{c}\text { Tu } \\
\text { nta } \\
\text { s }\end{array}$ & $\begin{array}{c}\text { Tidak } \\
\text { Tunta } \\
\text { s }\end{array}$ \\
\hline 1 & $\begin{array}{l}\text { Siti } \\
\text { Mahmudah }\end{array}$ & 70 & $\sqrt{ }$ & \\
\hline 2 & Kiptiyaningsih & 60 & & $\sqrt{ }$ \\
\hline 3 & $\begin{array}{lll}\text { Ahmad } & \text { Rozadi } & \text { Al } \\
\text { Baihaki } & & \end{array}$ & 80 & $\sqrt{ }$ & \\
\hline \multicolumn{3}{|c|}{ Jumlah } & 2 & 1 \\
\hline \multicolumn{3}{|c|}{ Prosentase } & $\begin{array}{l}67 \\
\%\end{array}$ & $33 \%$ \\
\hline
\end{tabular}

\section{Gambar 1. Grafik Hasil Belajar Matematika Siklus I}

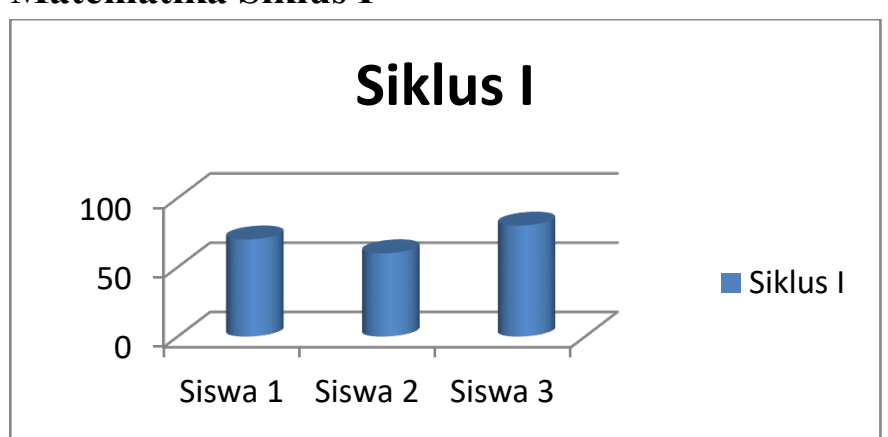

Dari tabel dan grafik di atas dapat dijelaskan bahwa dengan menerapkan pembelajaran dengan Media Papan Berpaku diperoleh nilai rata-rata hasil belajar siswa adalah 70 dan ketuntasan 
belajar mencapai $67 \%$ atau ada 2 siswa dari 3 siswa sudah tuntas belajar. Hasil tersebut menunjukkan bahwa pada siklus pertama secara klasikal siswa belum tuntas belajar, karena siswa yang memperoleh nilai $\geq 65$ hanya sebesar $67 \%$ lebih kecil dari persentase ketuntasan yang dikehendaki yaitu sebesar 85\%. Hal ini disebabkan karena siswa masih merasa baru dan belum mengerti apa yang dimaksudkan dan digunakan guru dengan menggunakan Media Papan Berpaku.

Dalam pelaksanaan refleksi kegiatan belajar mengajar diperoleh informasi dari hasil pengamatan sebagai berikut:

1) Kelebihan

a) Media Papan Berpaku sudah dapat diterapkan dan dapat mengurangi metode ceramah yang sering digunakan selama ini.

\section{1)}

b) Ketuntasan hasil belajar mengalami peningkatan dari 33\% (sebelum siklus) menjadi 67\% (setelah siklus I).

2) Kelemahan:

a) Pada siklus I masih belum?) menunjukkan hasil yang memuaskan bahwa kemampuan siswa dalam memahami materi dengan menggunakan Mediä) Papan Berpaku.

b) Sekalipun ketuntatas hasil belajar siswa mengalami peningkatan dari sebelum siklus dengan setelah siklus I, namun belum mencapai ketuntasan yaitu $85,00 \%$.

3) Fakor Yang Menyebabkan:

a) Guru kurang baik dalam memotivasi siswa dan dalam
menyampaikan
tujuan
pembelajaran
b) Guru kurang baik dalam pengelolaan waktu
c) Siswa kurang begitu antusias selama pembelajaran berlangsung.

4) Alasan Tindakan Perbaikan:

a) Karena ketuntatas hasil belajar siswa secara klasikan belum mencapai ketuntasan yaitu $85,00 \%$.

b) Karena penggunaan Media Papan Berpaku pada siklus kurang maksimal dan memotivasi antusias siswa.

\section{Siklus II}

Pelaksanaan kegiatan belajar mengajar pada siklus I masih terdapat kekurangan, sehingga perlu adanya revisi untuk dilakukan pada siklus berikutnya. Revisi tersebut antara lain:

Guru perlu lebih terampil dalam memotivasi siswa dan lebih jelas dalam menyampaikan tujuan pembelajaran. Dimana siswa diajak untuk terlibat langsung dalam setiap kegiatan yang akan dilakukan.

Guru perlu mendistribusikan waktu secara baik dengan menambahkan informasi yang dirasa perlu dan memberi catatan.

Guru harus lebih terampil dan bersemangat dalam memotivasi siswa sehingga siswa bisa lebih antusias.

Pada tahap ini peneliti menyusun perangkat pembelajaran yang terdiri dari rencana pelajaran 2, LKS 2, soal tes formatif 2 dan alat-alat pembelajaran yang mendukung. Selain itu juga dipersiapkan lembar observasi pengelolaan pembelajaran dengan Media 
Papan Berpaku dan lembar observasi aktivitas guru dan siswa.

Pelaksanaan kegiatan belajar mengajar untuk siklus II dilaksanakan pada tanggal 16 - 23 Juli 2015 di Kelas IX dengan jumlah 3 anak. Dalam hal ini peneliti bertindak sebagai guru, sedangkan yang bertindak sebagai pengamat adalah teman sejawat. Adapun proses belajar mengajar mengacu pada rencana pelajaran dengan memperhatikan refisi pada siklus I, sehingga kesalahan atau kekurangan pada siklus I tidak terulang lagi pada siklus II. Pengamatan (observasi) dilaksanakan bersamaan dengan pelaksanaan belajar mengajar.

Pada akhir proses belajar mengajar siswa diberi tes formatif 2 dengan tujuan untuk mengetahui tingkat keberhasilan siswa dalam proses belajar mengajar yang telah dilakukan. Adapun data hasil belajar Matematika pada siklus II adalah sebagai berikut:

Tabel 4.2. Hasil Belajar Matematika pada Siklus II

\begin{tabular}{|c|l|c|c|c|}
\hline $\begin{array}{l}\text { N } \\
\mathbf{0}\end{array}$ & Nama & $\begin{array}{c}\text { Ni } \\
\text { lai }\end{array}$ & $\begin{array}{c}\text { Tunta } \\
\mathbf{s}\end{array}$ & $\begin{array}{c}\text { Tida } \\
\mathbf{k} \\
\text { Tunt } \\
\mathbf{a s}\end{array}$ \\
\hline 1 & $\begin{array}{l}\text { Siti Layinatul } \\
\text { Mahmudah }\end{array}$ & 70 & $\sqrt{ }$ & \\
\hline 2 & Kiptiyaningsih & 75 & $\sqrt{ }$ & \\
\hline 3 & $\begin{array}{l}\text { Ahmad Rozadi } \\
\text { Al Baihaki }\end{array}$ & 85 & $\sqrt{ }$ & \\
\hline \multicolumn{3}{|c|}{ Jumlah } & 3 & 0 \\
\hline \multicolumn{3}{|c|}{ Prosentase } & $100 \%$ & $0 \%$ \\
\hline
\end{tabular}

Gambar 4.2. Grafik Hasil Belajar Matematika Siklus II

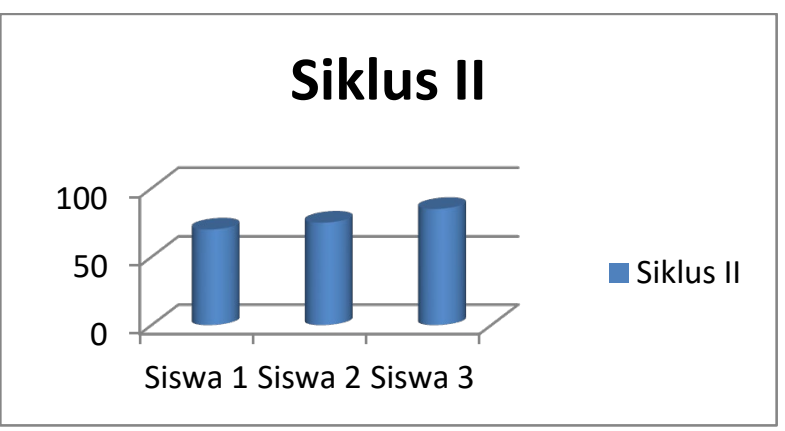

Berdasarkan tabel dan grafik di atas diperoleh nilai rata-rata tes formatif sebesar 77 dan dari 3 anak telah tuntas semua. Maka secara klasikal ketuntasan belajar yang telah tercapai sebesar 100\% (termasuk kategori tuntas). Hasil pada siklus II ini mengalami peningkatan lebih baik dari siklus I. Adanya peningkatan hasil belajar pada siklus II ini dipengaruhi oleh adanya peningkatan kemampuan guru dalam menerapkan pembelajaran dengan Media Papan Berpaku membuat siswa menjadi lebih terbiasa dengan pembelajaran seperti ini sehingga siswa lebih mudah dalam memahami materi.

Pada tahap ini akah dikaji apa yang telah terlaksana dengan baik maupun yang masih kurang baik dalam proses belajar mengajar dengan penerapan pembelajaran dengan Media Papan Berpaku. Dari data-data yang telah diperoleh dapat duraikan sebagai berikut:

1) Selama proses belajar mengajar guru telah melaksanakan semua pembelajaran dengan baik. Meskipun ada beberapa aspek yang belum sempurna, tetapi persentase pelaksanaannya untuk masingmasing aspek cukup besar. 
2) Berdasarkan data hasil pengamatam diketahui bahwa siswa aktif selama proses belajar berlangsung.

3) Kekurangan pada siklus-siklus sebelumnya sudah mengalami perbaikan dan peningkatan sehinggla. menjadi lebih baik.

4) Hasil belajar siswa pada siklus II mencapai ketuntasan.

Pada siklus II guru telah menerapkan pembelajaran dengan Media Papan Berpaku dengan baik dan dilihad. dari hasil belajar siswa pelaksanaan proses belajar mengajar sudah berjalan dengan baik. Maka tidak diperlukan revisi terlalu banyak, tetapi yang perlu diperhatikan untuk tindakah selanjutnya adalah memaksimalkan daib. mempertahankan apa yang telah ada dengan tujuan agar pada pelaksanaan proses belajar mengajar selanjutnya penerapan pembelajaran dengan Media. Papan Berpaku dapat meningkatkan proses belajar mengajar sehingga tujuan pembelajaran dapat tercapai.

Adapun perbandingan antara kedua Siklus di atas, dapat dilihat pada tabel berikut ini:

Tabel 4.3. Perbandingan Hasil Belajar Matematika Siklus I dan II

\begin{tabular}{lcrcc}
\hline $\begin{array}{l}\text { Katego } \\
\text { ri }\end{array}$ & \multicolumn{2}{c}{$\begin{array}{c}\text { Siklus } \\
\text { I/Prosentase }\end{array}$} & \multicolumn{2}{c}{$\begin{array}{c}\text { Siklus } \\
\text { II/Prosesentase }\end{array}$} \\
\hline Tuntas & 3 & $67 \%$ & 3 & $100 \%$ \\
\hline $\begin{array}{l}\text { Belum } \\
\text { Tuntas }\end{array}$ & 1 & $33 \%$ & 0 & $0 \%$ \\
\hline
\end{tabular}

Hasil penelitian pembelajaran pada siklus I, untuk peningkatan hasil belajar Matematika tentang Kesebangunan Bangun Datar di Kelas IX SLB-A (Tunanetra) TPA Jember masih belum sepenuhnya dipahami anak. Beberapa hal yang menyebabkan ini adalah:
Siswa kurang termotivasi untuk belajar Matematika, serta strategi pembelajaran yang diterapkan guru masih belum bisa membuat siswa aktif dalam pembelajaran di kelas.

Hasil belajar akhir siklus pembelajaran ke I ini semakin meningkat dibanding sebelum siklus, dari rata-rata ketuntasan $33 \%$ menjadi $67 \%$.

Pada siklus II ini pengamatan yang diperoleh adalah:

Keaktifan siswa untuk mengikuti pembelajaran semakin meningkat, karena pembelajaran dengan menggunakan Media Papan Berpaku lebih membuat semua siswa dapat berperan aktif secara merata.

Komunikasi antar guru dan siswa juga sering terjadi karena guru memperhatikan dan menghargai ide atau pendapat siswa.

Hasil belajar akhir siklus pembelajaran ke II ini semakin meningkat dibanding siklus I, dari rata-rata $67 \%$ menjadi $100 \%$. Dengan demikian, secara klasikal hasil belajar Matematika dinilai tuntas.

\section{PENUTUP}

\section{Simpulan}

Dari hasil kegiatan pembelajaran yang telah dilakukan selama dua siklus, dan berdasarkan seluruh pembahasan serta analisis yang telah dilakukan dapat disimpulkan bahwa: pembelajaran dengan Media Papan Berpaku memiliki dampak positif dalam meningkatkan hasil belajar Matematika tentang Kesebangunan Bangun Datar pada Siswa Kelas IX SLB-A (Tunanetra) TPA Jember. Hal ini dapat dilihat pada Siklus I, dari 3 siswa yang tuntas sebanyak 2 siswa (67\%) dan yang belum tuntas sebanyak 1 siswa (33\%). Sedangkan 
pada Siklus II, semua siswa telah tuntas (100\%). Jadi, setelah diadakan Siklus II hasil belajar siswa meningkat sebesar $33 \%$.

\section{Saran}

Peneliti menyampaikan saran sebagai berikut:

1. Kegiatan pembelajaran Matematika yang selama ini menggunakan strategi kurang meningkatkan hasil belajar siswa, keaktifan siswa dan pemahaman terhadap materi sebaiknya menggunakan pembelajaran yang aktif, efektif, menyenangkan sesuai dengan situasi dan kondisi yang ada.

2. Dengan melihat hasil belajar siswa menggunakan Media Papan Berpaku yang mengalami peningkatan, tentunya bisa dikembangkan dengan metode pembelajaran yang lain yang dianggap lebih efektif.

3. Dengan adanya perbaikan pembelajaran diharapkan dapat meningkatkan profesional guru dalam mengemban amanat sebagai guru yang profesional.

\section{DAFTAR PUSTAKA}

Arsyad, Azhar. 2002. Media Pembelajaran. Jakarta: Raja Grafindo Persada

Asnawir, \& Usman Basyiruddin, M. 2002. Media Pembelajaran. Jakarta: Ciputat Press

Depdiknas, 2003, Pembelajaran Matematika. Jakarta: Depdiknas

Dimyati, dan Mujiono, 2002, Belajar dan Pembelajaran, Jakarta: Rineka Cipta

Hamalik. 2007. Proses Belajar Mengajar. Jakarta: Bumi Aksara
Hamzah, 2007, Model Pembelajaran, Jakarta: PT. Bumi Aksara

Kemmis, S. dan Mc. Taggart, R. 1988. The Action Research Planner. Victoria Dearcin University Press

Lithanta, Agus. 2008. Penggunaan Alat Peraga Perkalian Teknik John Napiersebagai

Media Pembelajaran Matematika. Jakarta: Depdiknas

Mahfud. 1986. Media Pengajaran. Jakarta: PT. Raja Grafindo Persada

Marsigit, 2003, Wawasan tentang Strategi dan Aplikasi Pembelajaran Matematika Berbasis Kompetensi. Diakses dari http://staff.uny.ac.id/kepala sekolah/marsigit, pada tanggal 15 April 2015

Muksetyo, Gatoto, 2007, Pembelajaran Matematika, Jakarta: Uneversitas Terbuka

Mulyana, AZ. 2001. Rahasia Matematika. Surabaya: Edutama Mulya.

Poerwodarminto. 2007. Kamus Umum Bahasa Indonesia. Jakarta: Balai Pustaka

Prihandoko, 2006, Pemahaman dan Penyajian Konsep Matematika secara Benar dan Menarik. Jakarta: Dediknas

Purwadi, Agung, 2010, Meningkatkan Kreatifitas Pembelajaran Bagi Guru. Bandung: Remadja Rosda Karya

Purwanto, M. N. 1991. Prinsip-Prinsip dan Teknik Evaluasi Pengajaran. Bandung: Remaja Rosdakarya

Rohani, A. 1997. Media Instruksional Edukatif. Jakarta: Rineka Cipta 
Volume 3, No. 2 Januari 2020

Sardiman, A.M. 2003. Interaksi dan Motivasi Belajar Siswa. Jakarta: PT. Rajawali Press Grafindo Persada

Slameto. 1991. Belajar dan FaktorFaktor yang Mempengaruhinya. Jakarta: Rineka Cipta

Subarinah, Sri, 2006, Inovasi Pembelajaran Matematika SD, Jakarta: Depdiknas

Suherman, Eman dan Winataputra. 2001. Strategi Belajar Mengajar Matematika. Jakarta: Depdikbud

Wardani, dkk, 2014. Pemantapan Kemampuan Profesional (PKP) $P G S D$, Jakarta: Universitas Terbuka 